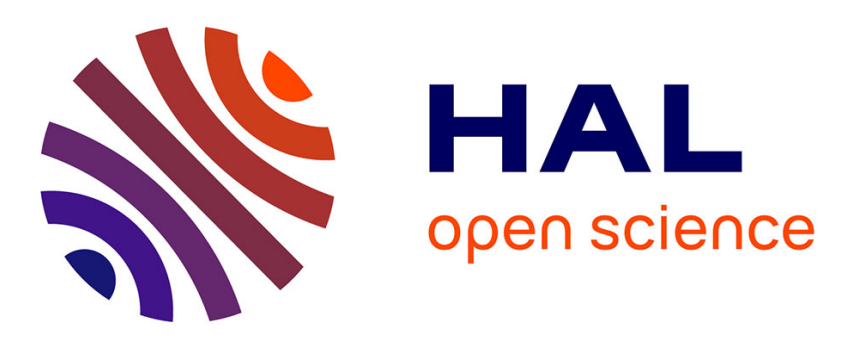

\title{
Comparison of the chondrogenic potential of mesenchymal stem cells derived from bone marrow and umbilical cord blood intended for cartilage tissue engineering
}

Romain Contentin, Thomas Branly, Julien Pestel, Miranda Concari, Mélanie

Desancé, Sandrine Jacquet, Lélia Bertoni, Fabrice Audigié, Magali Demoor, Philippe Galéra

\section{- To cite this version:}

Romain Contentin, Thomas Branly, Julien Pestel, Miranda Concari, Mélanie Desancé, et al.. Comparison of the chondrogenic potential of mesenchymal stem cells derived from bone marrow and umbilical cord blood intended for cartilage tissue engineering. Matrix Biology Europe MBE, 2018, Manchester, United Kingdom. hal-02294814

\section{HAL Id: hal-02294814 \\ https://hal.science/hal-02294814}

Submitted on 23 Sep 2019

HAL is a multi-disciplinary open access archive for the deposit and dissemination of scientific research documents, whether they are published or not. The documents may come from teaching and research institutions in France or abroad, or from public or private research centers.
L'archive ouverte pluridisciplinaire HAL, est destinée au dépôt et à la diffusion de documents scientifiques de niveau recherche, publiés ou non, émanant des établissements d'enseignement et de recherche français ou étrangers, des laboratoires publics ou privés. 
W《太N

UNIVERSITÉ CAEN NORMANDIE

\section{Comparison of the chondrogenic potential of mesenchymal stem cells derived from bone marrow and umbilical cord blood intended for cartilage tissue engineering}

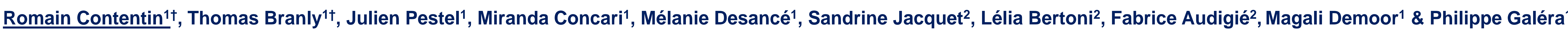
1. Unit BioTARGen, Team OErAGen EA 7450, UFR Santé, University of Caen Normandy, 14032 Caen, France.

2. Center of Imaging and Research on Locomotor Affections in Equines, Veterinary school of Alfort, University of Paris-East, 14430 Goustranville, France.

Introduction

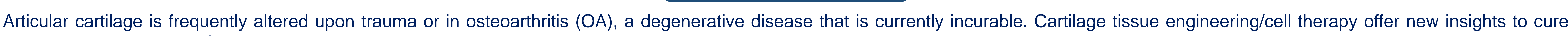

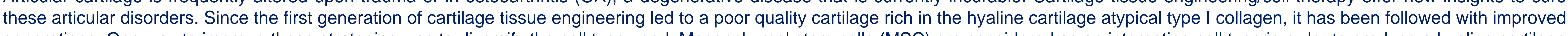

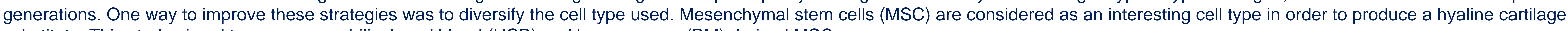
substitute. This study aimed to compare umbilical cord blood (UCB) and bone marrow (BM) derived MSC.

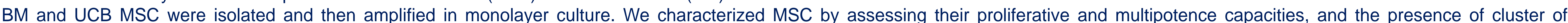

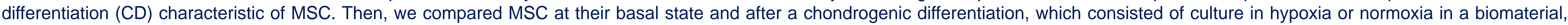

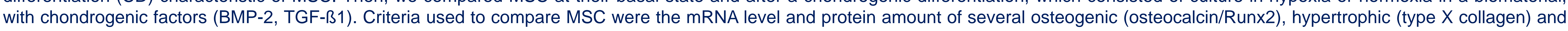
chondrogenic markers (type II collagen). Furthermore, we analysed the extracellular matrix(ECM) composition/structure by immunochemistry.

\section{Results}

\section{MSC isolation}

Equine UCB was collected by venipuncture of the umbilical veins and equine BM was collected from sternal puncture in a cohort of horses with ages ranging from 2 to 4 years. Then, MSC were isolated by density gradient centrifugation with Ficoll followed with a seed of the
interphase in a plastic flask filled with an isolation medium to select cells interphase in a plastic flask filled with an isolation medium to select cells
which were able to adhere and form colonies, the MSC. After the which were able to adhere and form colonies, the MSC. After the
appearance of several colonies, cells were detached using appearance of several colonies, cells were
trypsin/EDTA and then reseeded at $5000 \mathrm{cells} / \mathrm{cm}^{2}$

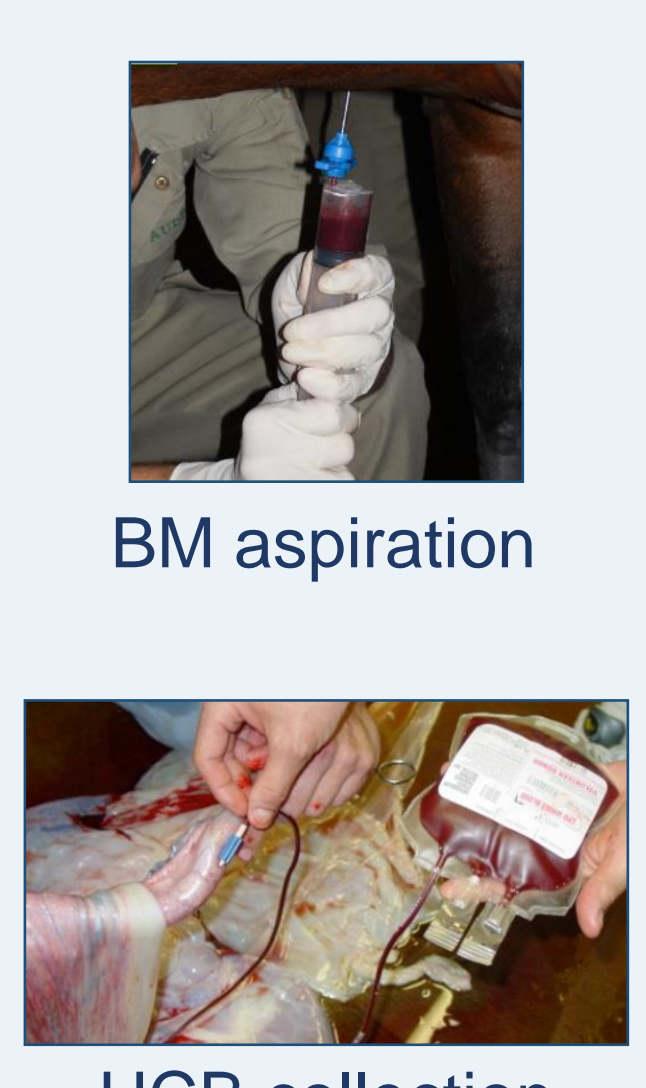

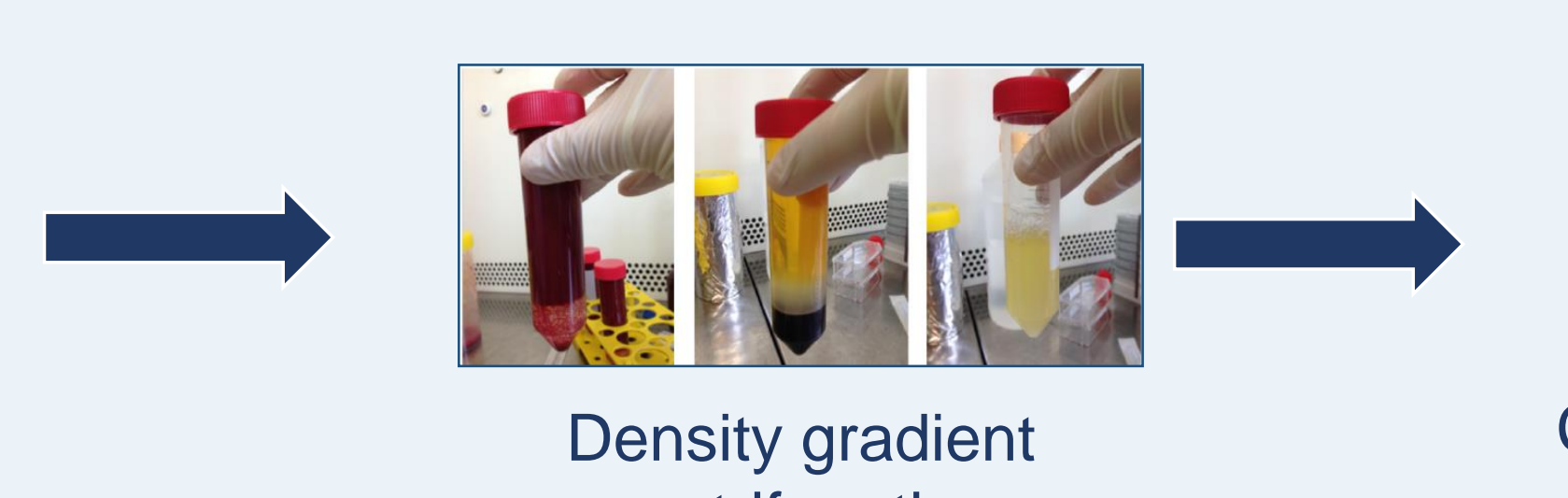

Density gradient
centrifugation
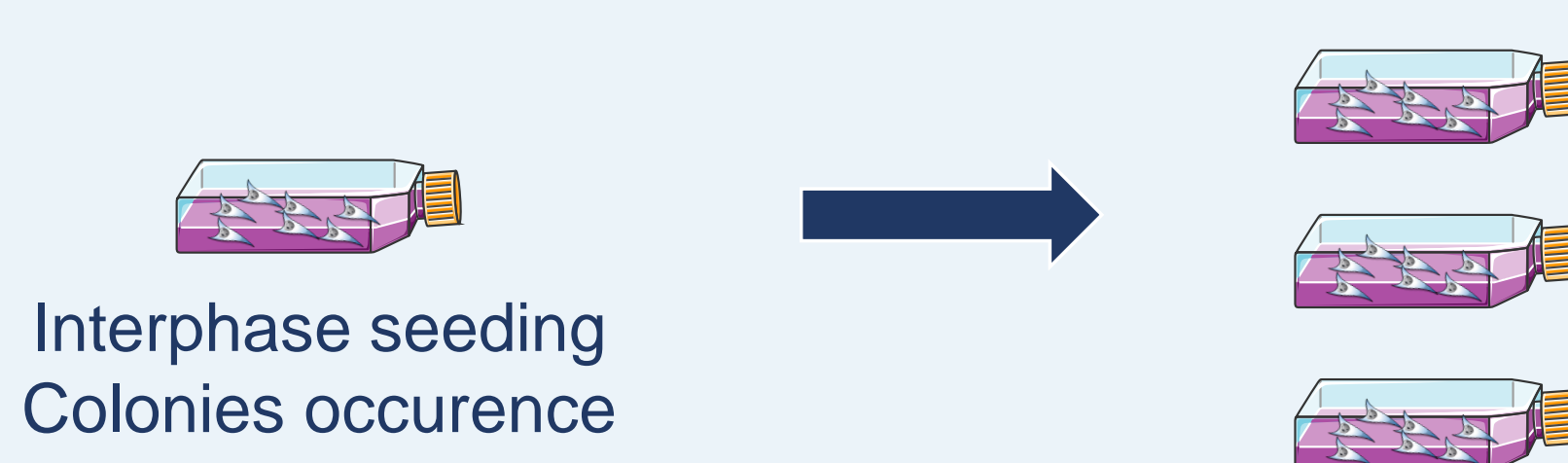

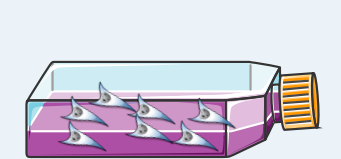

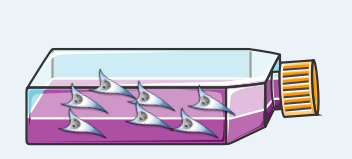

MSC amplification

\section{MSC characterization}

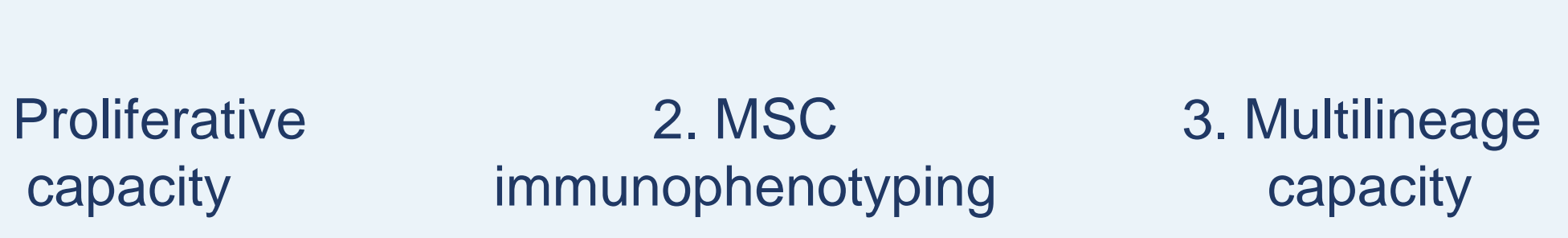

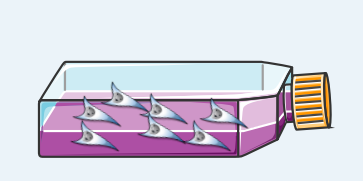

I

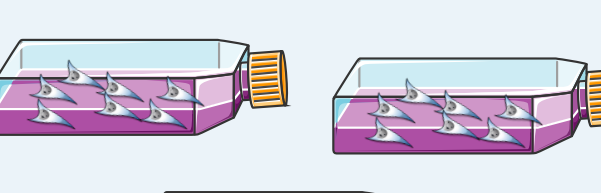
군궁 a

capacity
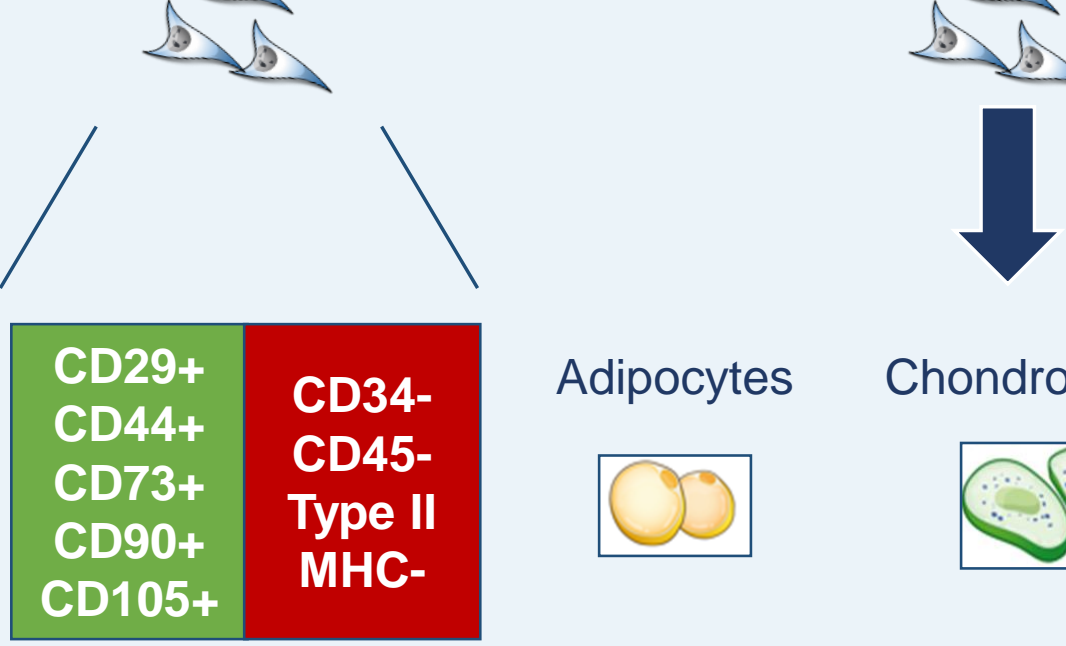

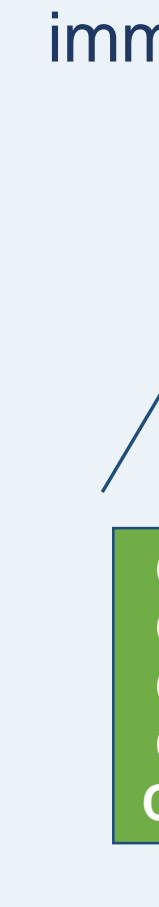

1. Proliferative capacity

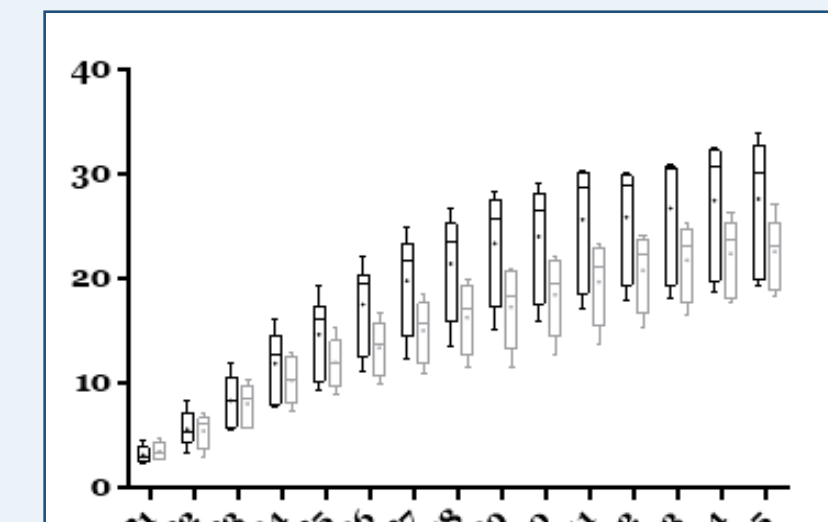

The MSC from the BM and UCB were isolated and seeded at 5000 seeding at the same cell density ( $\mathrm{n}=$ 4). The significance of the results
was evaluated using a Mann
Whitney test $(" p<0.05, * " * p<0.01$ cells/cm². A passage with
trypsin/EDTA was performed every days, followed by counting and ri
2. MSC immunophenotyping At P4, the cells were detached and
Suspended at 10 million cells per $m$ ml suspended at $10 \mathrm{~m}$ illino colls $\mathrm{ser}$ mI
in PBS. They were incubated with in PBS. They were incubated with
the indicated specific monoclonal sotype controls for 30 min at $4^{\circ} \mathrm{C}$ in a dark room. The cells were then
washed and resuspended in PBS The results are presented as the

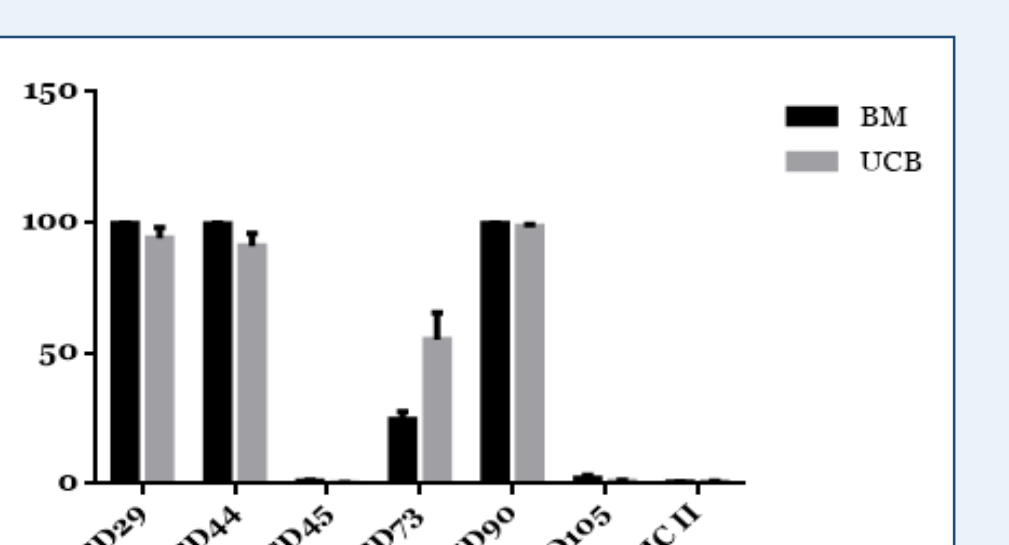
differences involved in their
MSC at their basal state

Because MSC could exhibit a comparison of both MSC at their basal state. Thus, during the mRNA (1) and protein (2) level analyses. amplification of MSC we performed

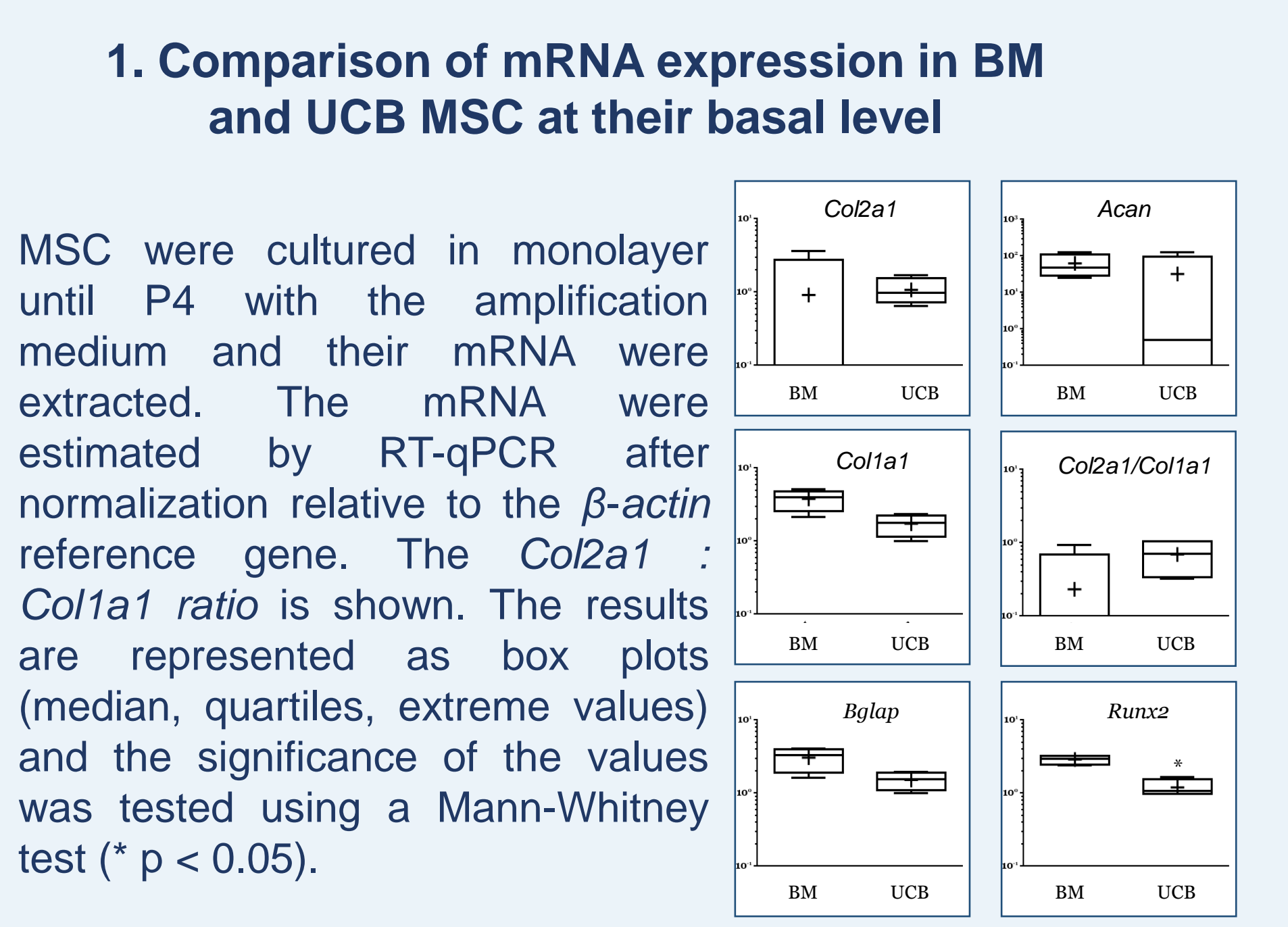

MSC after chondrogenic differentiation

Equine MSC derived from BM or UCB were seeded in collage sponges at $\mathrm{P} 4(\mathrm{n}=5)$. They were then grown in hypoxia $\left(3 \% \mathrm{O}_{2}\right)$ or
normoxia $\left(21 \% \mathrm{O}_{2}\right)$ for 14 and 28 days (D14 and $\left.\mathrm{D} 28\right)$ in the $(50 \mathrm{ng} / \mathrm{mll}$ ) and TGF- $-\beta 1(10 \mathrm{ng} / \mathrm{mll})$. The D0 condition corresponds to
$\mathrm{MSC}$ cultured in monolayer at P4 with the amplification medium and the equine articular cartilage $(\mathrm{AAC})$ condition corresponds to the
protein extracted from healthy cartilage.

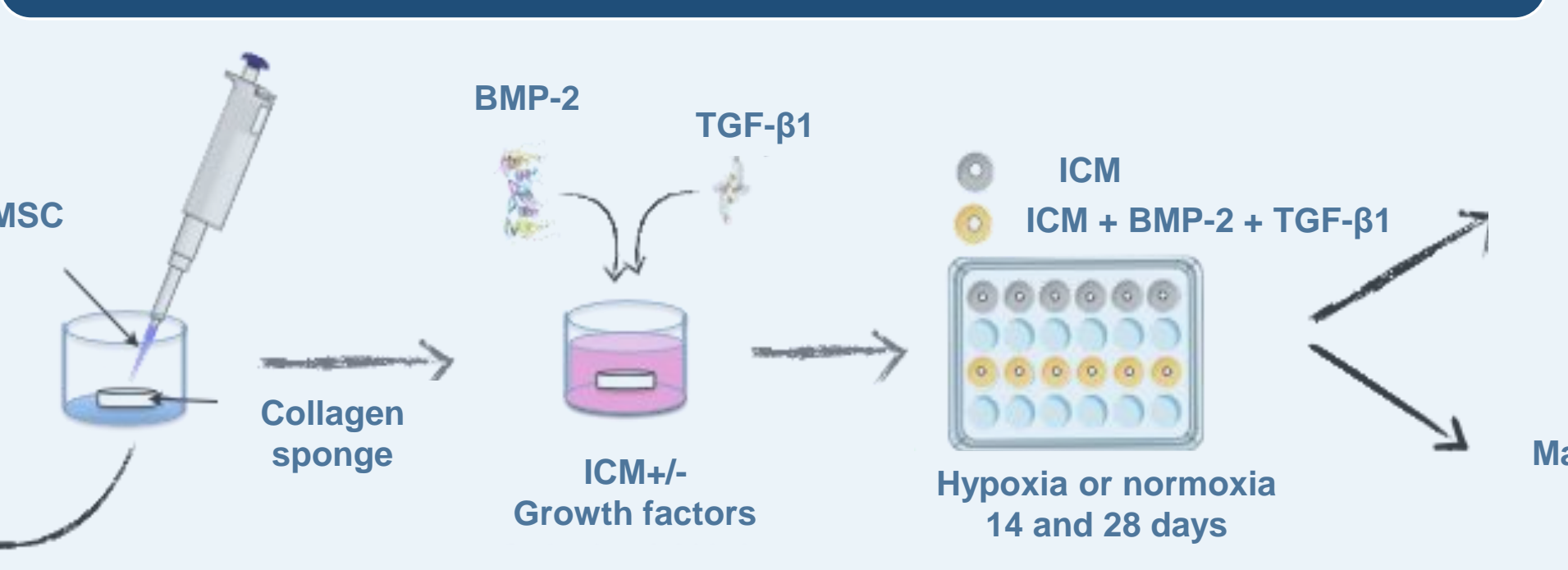

1. Effect of the chondrogenic differentiation of BM and UCB MS
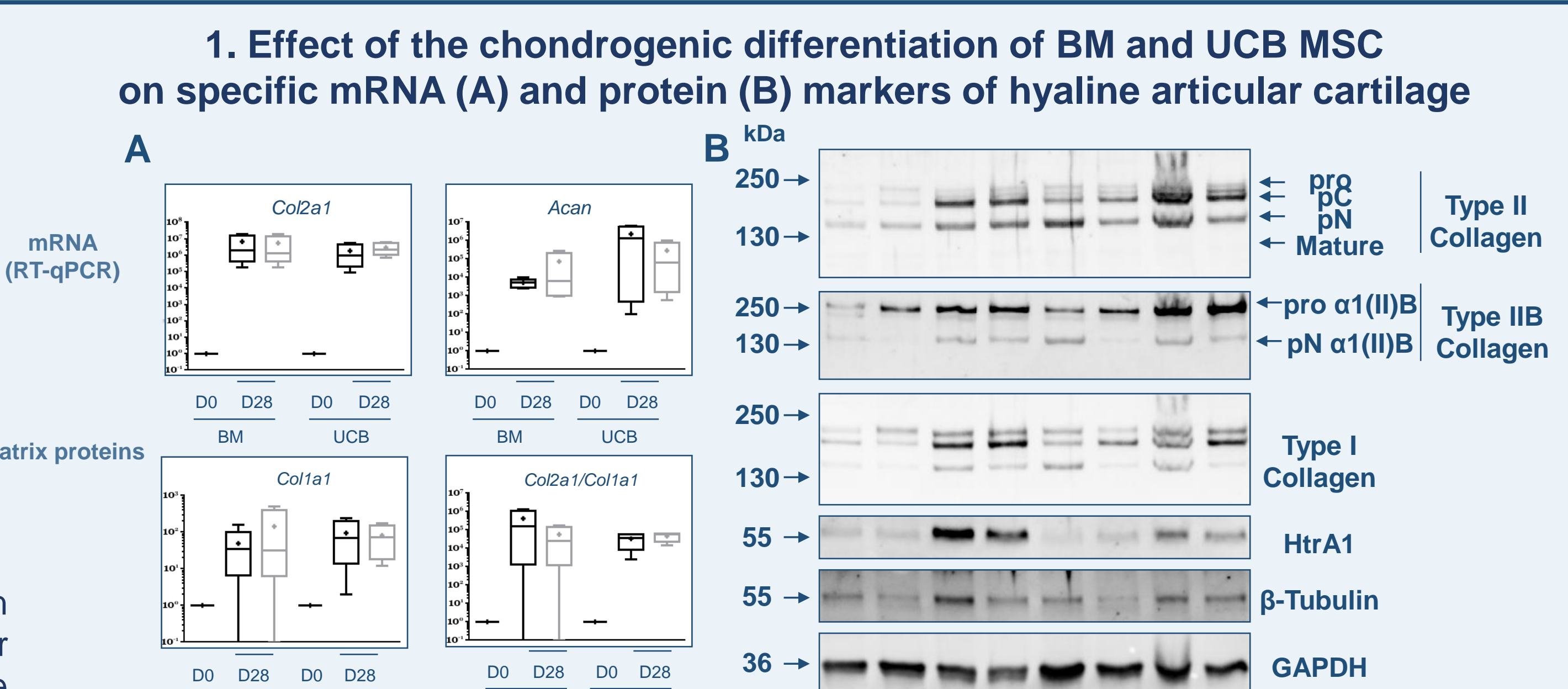

$\frac{\mathrm{N} H}{\mathrm{D} 14} \mathrm{BM}$

(A) MRNA levels were estimated by RT-gPCR after normalization relative to the $\beta$-action and the significance of the values was tested using a Mann-Whitney test $(" p<0.05$ ) (B) The total protein extracts were separated by electrophoresis on a $7.5 \%$ acrylamide gel under
denaturing conditions. The proteins were then transferred to a PVDF membrane which was
3. Multilineage capacity
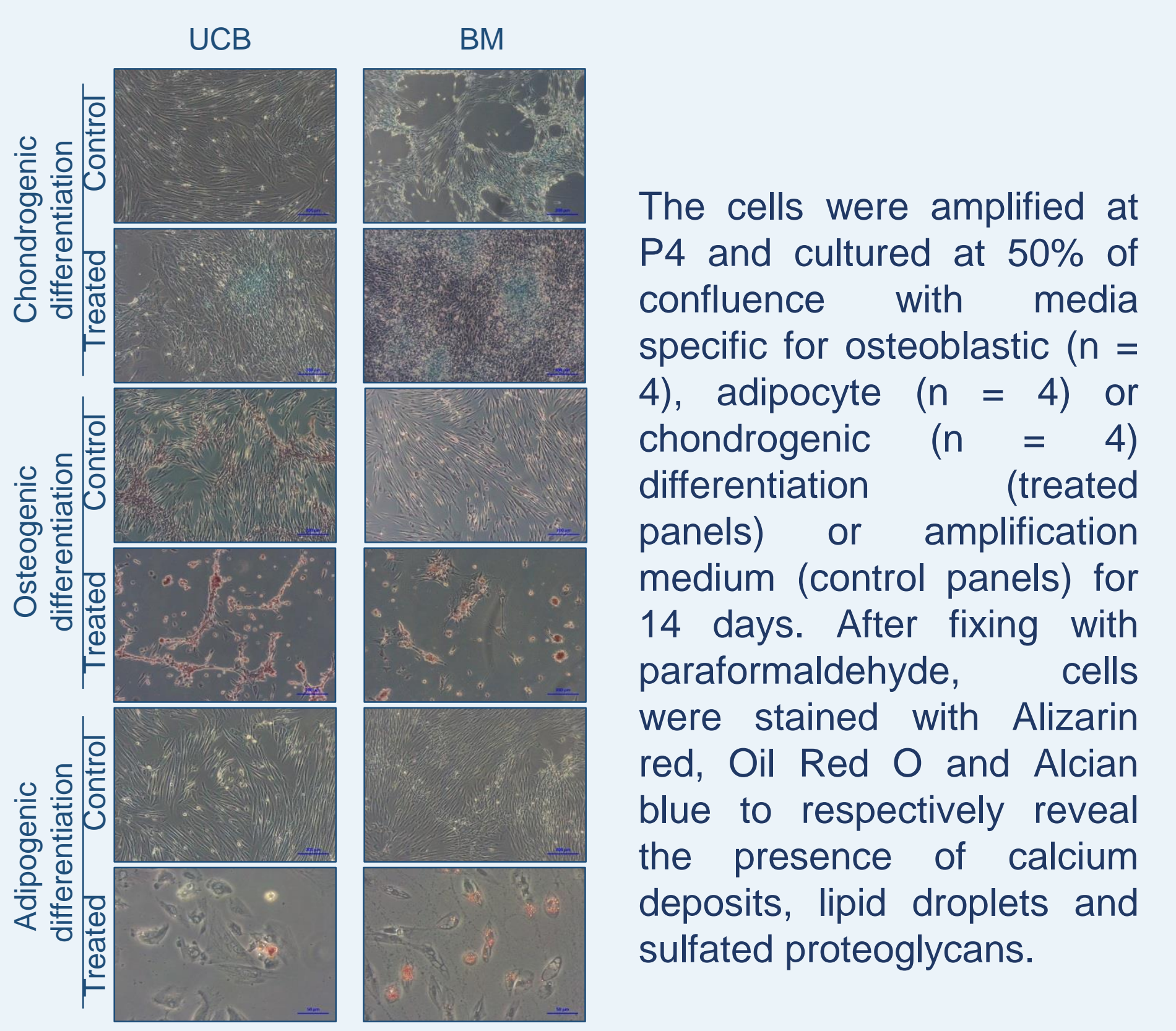

deposits, lipid droplets and
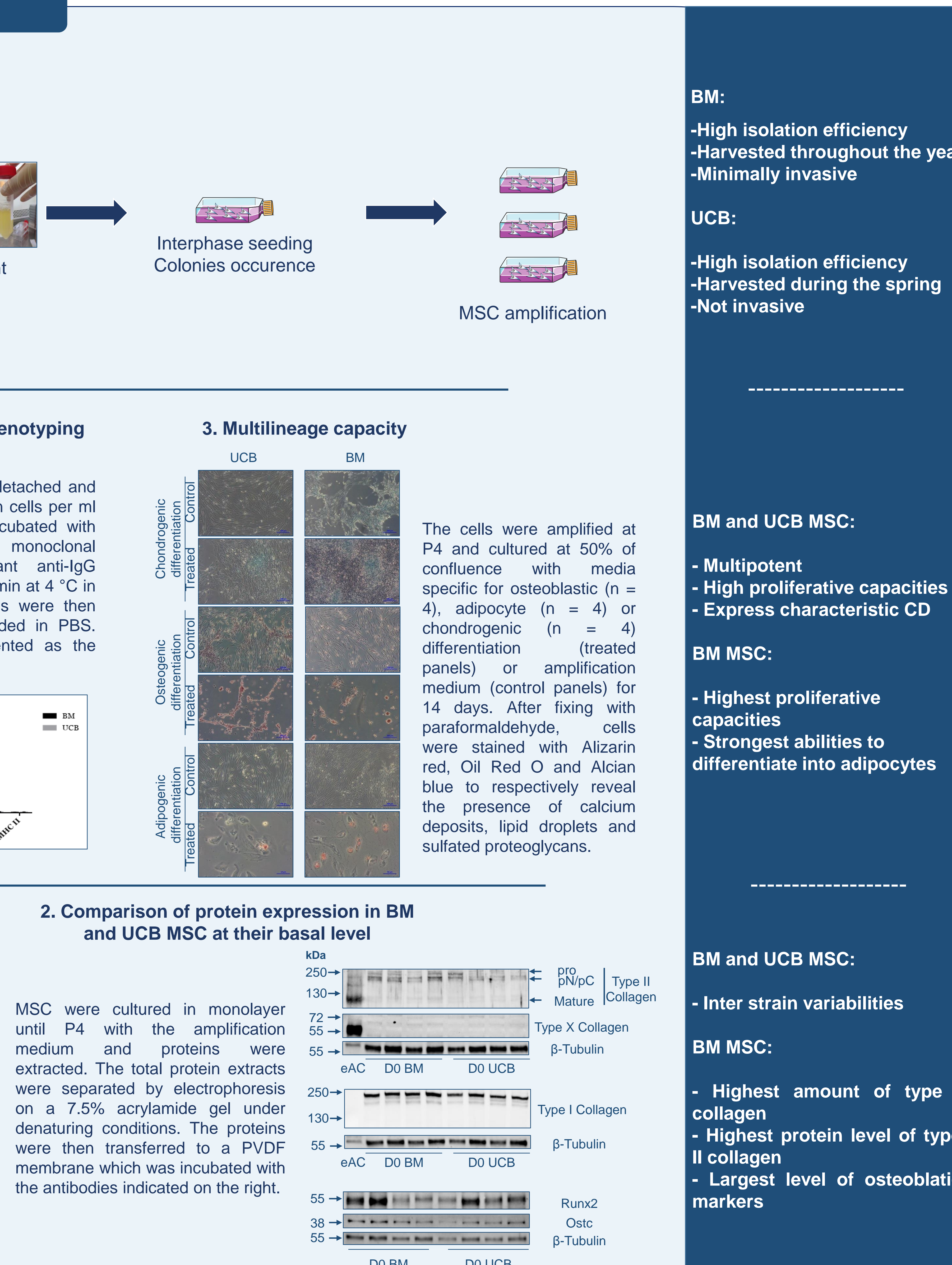

2. Assessment of the ECM

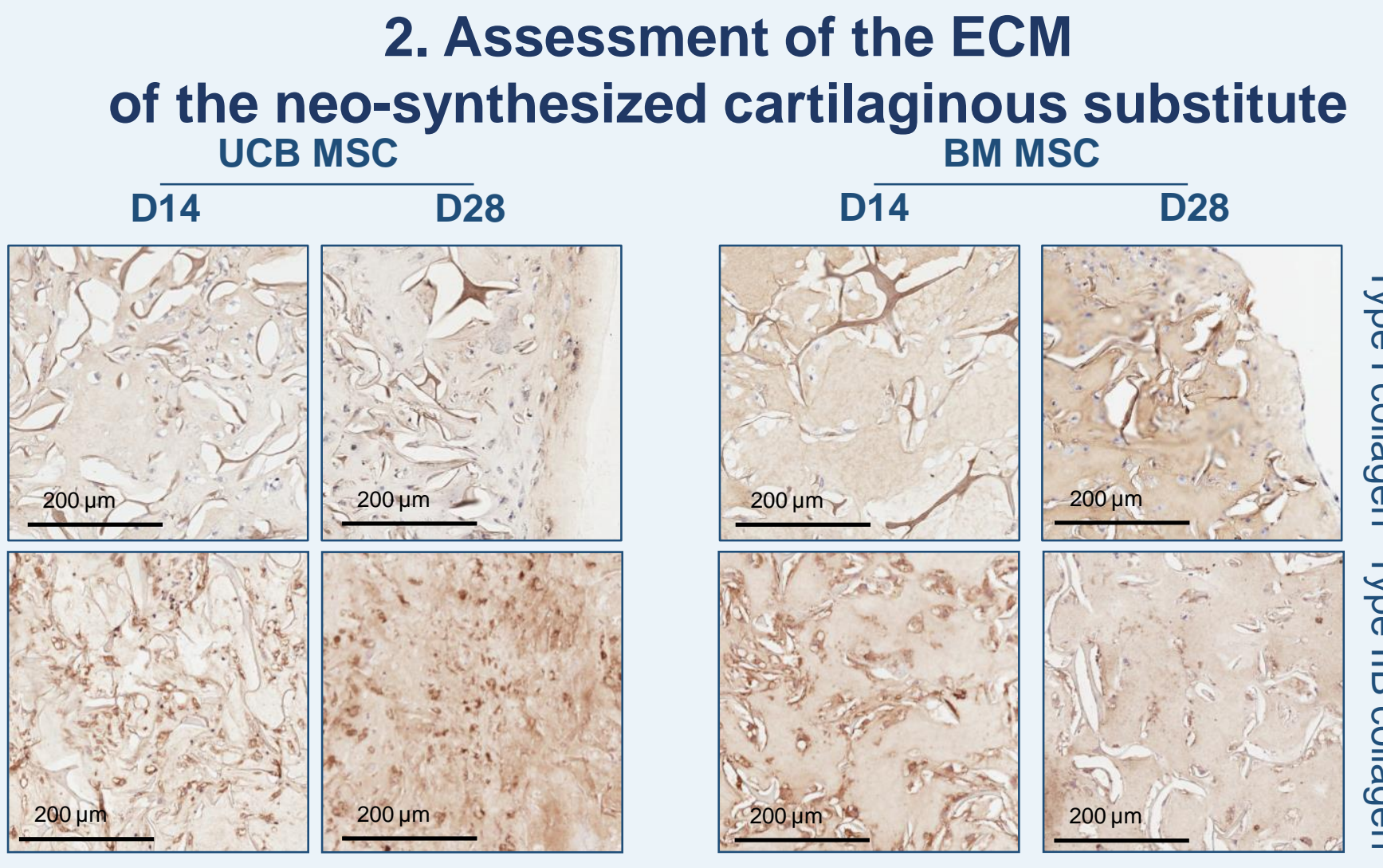

At D14 and at the end of the differentiation protocol, sponges were embedded in paraffin and sectioned in
$4 \mu \mathrm{\mu m}-$ thick slices. Then immunostaining was performed in
order to detect type I collagen or type IIB collagen.

促 - High proliferative capacities

BM MSC:

- Highest proliferative

capacities

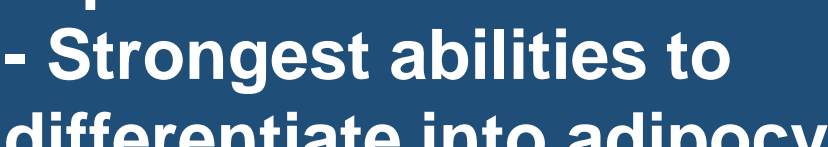

differentiate into adipocytes
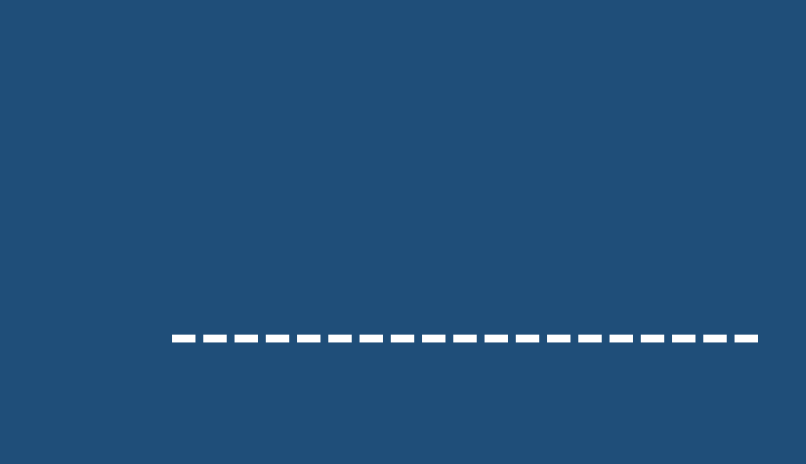

BM and UCB MSC:

- Inter strain variabilities

BM MSC:

Highest amount of type

collagen

Highest

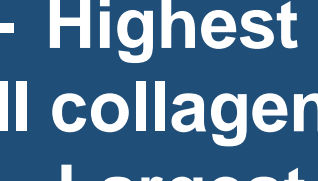

Largest level of osteoblatic

markers

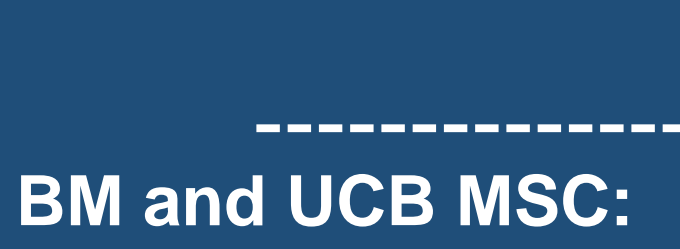

BM and UCB MSC:

- Hypoxia limits the

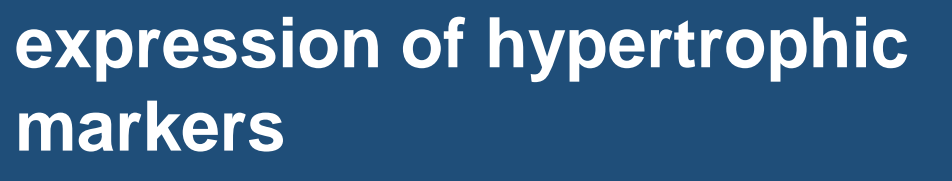

- Biomaterial is colonized with - No type I collagen at the - No type I collagen a
vicinity of the nuclei

UCB :

- Largest amount of ECM

BM :
.

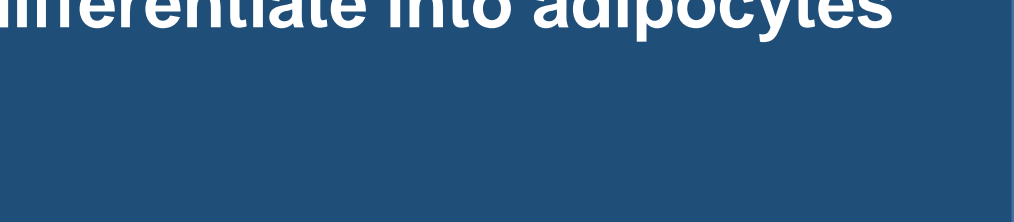
- Type I collagen decreases at

- Lower expression of HtrA1 - Lower protein amount of type I collagen

\section{Conclusions}

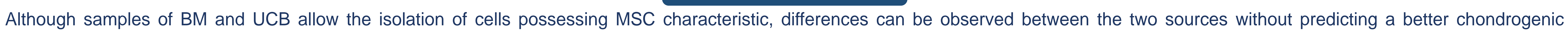

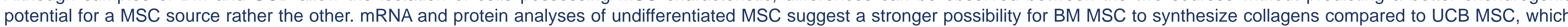

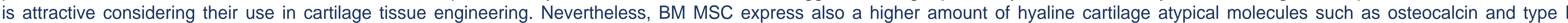

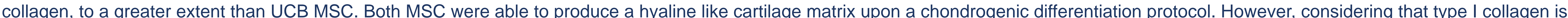

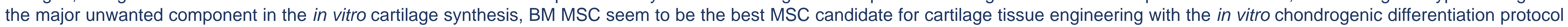

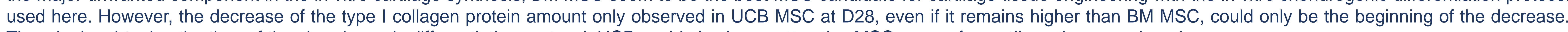
Thus, by lenghtening the time of the chondrogenic differentiation protocol, UCB could also be an attractive MSC source for cartilage tissue engineering. 